\title{
TOWARDS CRYSTALLIZING CIRCULAR BUSINESS MODELS: A CRITICAL ANALYSIS OF LITERATURE
}

\author{
AGNIESZKA KARMAN
}

Maria Sklodowska Curie University, Pl. M. Sklodowskiej 5, 20-031 Lublin, Poland.

*Corresponding author: agnieszka.karman@poczta.umcs.lublin.pl

Submitted final draft: 8 January $2020 \quad$ Accepted: 17 February $2020 \quad$ http://doi.org/10.46754/jssm.2020.08.014

\begin{abstract}
Circular Economy (CE) can be promoted and supported by the creation of new and innovative business models which embed CE principles into organisations' value chains. This paper provides a review of approaches to the circular business model $(\mathrm{CBM})$. We conducted a literature review, including content analysis, and examined publications (51 papers) on circular business models published in English in peerreviewed journals. Our objective was to provide an overview and systematize the stateof-the-art in CE-oriented business model approaches. The following research questions were posed in relation to the objective: Which sub-processes and components are included in the Circular Business Models (CBM)? Which CBM archetypes have already been established? Which strategies and other factors support the creation/ transformation of the CBM? The results of the studies were presented in five areas encompassing the following: 1) development (including the methodologies of development and transformation), value proposition, creation and delivery, 2) CBM archetypes, 3) circular strategies, 4) the determinants of development and transformation of business models for CE. The paper contributes to the improved understanding of circular business models. It consolidates related research by offering an overarching conceptual framework. It also points to the directions of future research.
\end{abstract}

Keywords: Sustainability, circular economy, business model.

\section{Introduction}

Circular economy (CE) is interpreted in various ways, either as a requirement for sustainability, a synergetic or beneficial relation, or a tradeoff. A premise is made that the term "circular economy" is a generic term for reducing, reusing and recycling activities conducted in the process of production, circulation and consumption (Naustdalslid, 2017). In an attempt to consolidate the topic, many authors have argued that circular economy is a narrower concept than sustainability, and have highlighted its economic and environmental dimension, but neglected the social perspective (Geissdoerfer et al., 2017). In the idealised vision, by rearranging the flow of materials and energy, $\mathrm{CE}$ reduces inputs to the system and waste and emission outputs from the system (e.g., Korhonen et al., 2018). Given the significance of CE for the socioeconomic development, the question of how businesses become engaged in the realisation of the concept arises. When searching for theoretical, conceptual and practical guidelines enabling $\mathrm{CE}$ to be transplanted onto the microeconomic dimension, one finds emerging conceptual literature (Hobson \& Lynch, 2016; Witjes \& Lozano, 2016). By employing diverse approaches, it indicates the method allowing CE principles to be implemented. Such considerations assume various degrees of abstraction.

The transition towards circular economy requires organisations to rethink and redesign their current business models in a radically disruptive manner (Lieder \& Rashid, 2016; Aminoff et al., 2017). In practice, the development of CE is supported by new and innovative business models (Bocken et al., 2016; Lewandowski, 2016) which embed CE principles into value propositions throughout value chains. Undeniably, the acquisition of value from pro-environmental actions has already been practised. There are several approaches to business models one could potentially draw 
upon. For example, sustainable development has pushed the agenda for businesses to engage in social and ecological issues and has also developed models that organisations can harness to generate economic gains from the engagement (Bryant \& Wilson, 1998; Hart, 1997). Furthermore, the literature features the neo-institutional theory as an alternative, which has been applied to the environmental engagement of organisations (Sarasini \& Jacob, 2014). However, studies pertaining to Circular Business Models (CBM) have not been around for long. Propositions of the archetypes of new, dedicated business models emerge, as well as recommendations pertaining to embedding circularity in the classical models. However, they are frequently incompatible. In addition, references to sustainability introduce additional confusion and anxiety (Lüdeke-Freund \& Dembek, 2017). This leads to difficulties in interpretation, but more importantly, problems for practitioners for whom a business model (BM) may constitute a path to the transition to $\mathrm{CE}$. As a consequence, there is a need for consolidation - the accumulation of theoretical and conceptual works regarding the CBM, which could enhance knowledge.

The main objective of this paper is to systematise the state-of-the-art of available approaches and archetypes of the CBM. Our research contributes to field which verges upon $\mathrm{CE}$ and BM by providing: 1) the review and systematisation of CBM archetypes presented in literature, 2) the analysis of elements (sub-processes) forming a value chain in the organisation, 3) improved understanding of the way the determinants of CBM development exert an impact upon outcomes.

After the initial discussion of circular economy and business models (Sections 2 and 3 ), the methodology of the study will be outlined (Section 4). Next, methodological propositions pertaining to the transformation of traditional business models into circular business models will be discussed (Section 5). Subsequently, the sub-processes of the value chain and CBM archetypes will be outlined (Sections 6 and 7). Section 8 will discuss circular strategies. Section
9 will outline works devoted to determinants. The final section will discuss conclusions regarding the usefulness and implications of this study, as well as its limitations and recommendations for future research.

\section{Circular Economy - introduction to the concept}

For the first time, the term CE appeared in a study by Pearce and Turner (1990) which addressed the interlinkages between the environment and economic activities (Andersen, 2007). The authors identified a closed-loop material flow in which the economic system occupies the position following the principle "everything is an input to everything else" (Su et al., 2013). Nevertheless, CE principles date back to the work of Boulding (1966), who introduced the idea of a closed system as a solution to the problem of limited natural resources (Nebbia, 2000). The definition of CE contains a broad spectrum of components and principles, including regenerative design (Lyle, 1994), performance economy (Stahel, 2008), cradle-to-cradle (Braungart et al., 2007) and industrial ecology (Erkman, 1997). This stems from its multi-disciplinarity rooted in different disciplines and schools. In particular, $\mathrm{CE}$ can be characterised by biogeochemical and technical cycles (Murray et al., 2015). The biogeochemical or biological cycles target the reduction in the extraction of natural resources and the management of renewable resource flows. By the implementation of the concept of the 3Rs -Reduce, Reuse, and Recycle - technical cycles aim to obtain the value of waste by circulating the waste as a source of raw materials across supply chains. The biogeochemical and technical cycles are driven by three principles (The Ellen MacArthur Foundation, 2015): (a) control the balance between the finite stock and renewable resource flows; (b) circulate the use of materials, components, and products; and (c) minimise the negative externalities of production and consumption systems by applying new business models.

From the perspective of enterprises, CE is perceived as the impetus for an economic 
development with an alternative flow model, which is cyclical and regenerative (EMAF, 2015; EMAF, 2013; EMAF, 2012; CIRAIG, 2015; Geissdoerfer et al., 2017). It provides opportunities for new value creation, business growth and increase in profits (World Economic Forum, 2014; Linder \& Williander, 2015). It also has the potential for innovation (Schulte, 2013; Kok et al., 2013) and achieving synergy benefits (Dong et al., 2016). The businessoriented CE approach emphasises product, component and material reuse, remanufacturing, refurbishment, repair, cascading and upgrading as well as the potential of sustainable energy sources such as solar, wind, biomass and waste-derived energy utilisation throughout the product value chain using a cradle-to-cradle life cycle approach (EMAF, 2013; Rashid et al., 2013; Mihelcic et al., 2003; Braungart et al., 2007). Drivers for circular economy were outlined in Tura et al. (2019). Although CE has received increasing attention among academics, the practical implementation of CE principles in organisations has been relatively rare (Schulte, 2013). As a consequence, there arose a popular need for studies in the microeconomic aspect of CE. Furthermore, by embracing the strategic orientation, the issue of CE-oriented business models can be focused upon.

\section{Business Model Perspective}

A Business Model represents a set of strategic decisions which define how organisations create, transfer and capture value according to their internal activities and relationships with stakeholders. For several years, the literature on strategic management has studied the role of the business model as a means to shape the strategy of companies. Indeed, the business model represents the sources of competitiveness, defining ones market position against competitors. Zott et al. (2011) distinguished three streams of research on business models. The first is concerned with the use of ICT to create, capture and deliver value via a new set of channels. The second is concerned with the interplay between business models and corporate strategy, and has focused on the influence of business models on companies' performance. Here, business models have been characterised as activity systems, which are defined as: "the content, structure, and governance of transactions designed so as to create value through the exploitation of business opportunities" (Zott \& Amit, 2010). The third stream is concerned with technology and innovation management, and characterises business models as "the organisational and financial architecture of the business" (Teece, 2010). In this stream, BM frameworks focus upon the creation of value of a reference system (e.g. organisation, value chain, industry sector), which can be represented by different elements (Wirtz et al., 2016).

In general, a business model is based on three main elements (Boons \& Lüdeke-Freund, 2013; Osterwalder \& Pigneur, 2010): (1) value proposition; (2) value creation and delivery; and (3) value capture. Value proposition addresses the needs of target customers through product/service offerings and through customer relationships, and also represents the competitive advantage of a company. Value creation and delivery refer to the company's resources, technologies and relationship networks which offer a competitive advantage and create customer value. Value capture refers to the cost structure and revenue streams (D'Amato et al., 2018). One of the most referenced representations, the BM Canvas, considers nine building blocks for value generation. These are organised in four pillars: product/ value proposition, financial aspects, customer interface and infrastructure management (Osterwalder et al., 2005). These four pillars are further refined by Richardson (2008) in three main forms of managing value: 'value proposition', 'value creation and delivery' and 'value capture'. Such representations are related to the static view of the BM. In parallel, there is the notion of BM innovation, which consists of changing the $\mathrm{BM}$ in response to internal and external incentives. In such a context, the BM functions as an innovation itself and constitutes a source of competitive advantage. 
Theoretical foundation of the business model concept is built on transaction- cost economics, resource-based view and dynamic capabilities (Barney et al., 2001; Zott et al., 2011). In relation to the CBM, the archetype ought to be searched for in the sustainabilityoriented BM. The sustainability-oriented BM incorporates sustainability principles as guidelines for the BM design, adding complexity to the conventional ('business as usual') BMI process (Lüdeke-Freund, 2010; Stubbs \& Cocklin, 2008). The CE-oriented $\mathrm{BM}$ incorporates principles or practices from $\mathrm{CE}$ as guidelines for the $\mathrm{BM}$ design. Based on the existing literature on Circular Economy and Business Model we agree that the adoption of a Circular Economy model requires the hitherto business model to be adapted or a new one created (Mathews \& Tan, 2011; Yang \& Feng, 2008). Taking CE principles as a reference point, the $\mathrm{CE}$ circular business model can be defined as the rationale of how an organisation creates, delivers, and captures value to close and slow material loops (Antikainen \& Valkokari, 2016; Bocken et al., 2016a). The CBM should be based on the reduction of the dependence on virgin materials, a shift from a carbon-based energy system to a renewable one, an increase in the adoption of sustainable production practices and adjustment of their value chain strategies (Antikainen \& Valkokari, 2016). Such changes (Yong, 2007; Yuan et al., 2006; Ünal et al., 2018) require a close cooperation from organisations and interaction with an ecosystem and stakeholders, moving from a firm-centric to a systemic or network-centric orientation (Bocken et al., 2016; Aminoff, 2017).

The literature review identified over twenty developed approaches to support the circular business model. They comprise conceptual models, methods or tools which are in a large majority theoretical. However, case study research results also begin to emerge. Their analysis will be discussed in further sections.

\section{Research methodology}

The main objective of this paper is to systematise the state-of the-art concerning the available approaches and archetypes of the CBM. The following research questions were posed in relation to the objective:

1) Which sub-processes and components are included in the CBM?

2) Which CBM archetypes have already been established?

3) Which strategies and other factors support the creation/ transformation of the CBM?

The paper will omit the discussion of meso-level considerations. The following were omitted: studies oriented at the society level (Hobson \& Lynch, 2016; Scheel, 2016) or investigating $\mathrm{CE}$ at the regional (,Geng et al., 2009), provincial (Ormazabal et al., 2016; Du et al., 2009) or national level (van Buren et al., 2016; Yaduvanshi et al., 2016). Our considerations were focused on the level of the organisation. We adopted the business model component approach which has recently been proposed by Clauss (2016) and Foss \& Saebi (2016). Hereafter, we refer the business model concept to the set of sub-processes which connects the value of the venture with the organisation's ability to generate profit.

As the topic is quite abstract, methodological choices were limited. We analysed the existing publications and employed them as "primary material" (Jauch et al., 1980). This is the typical approach of a literature review, which was combined with a content analysis. This might by now be called an established approach as it has been applied in a number of papers, and the research method is presented as a means in itself (Seuring \& Gold, 2012).

The individual steps of the research process will be explained. To ensure validity and reliability, a process model proposed by Mayring (2003) was followed (Figure 1). 


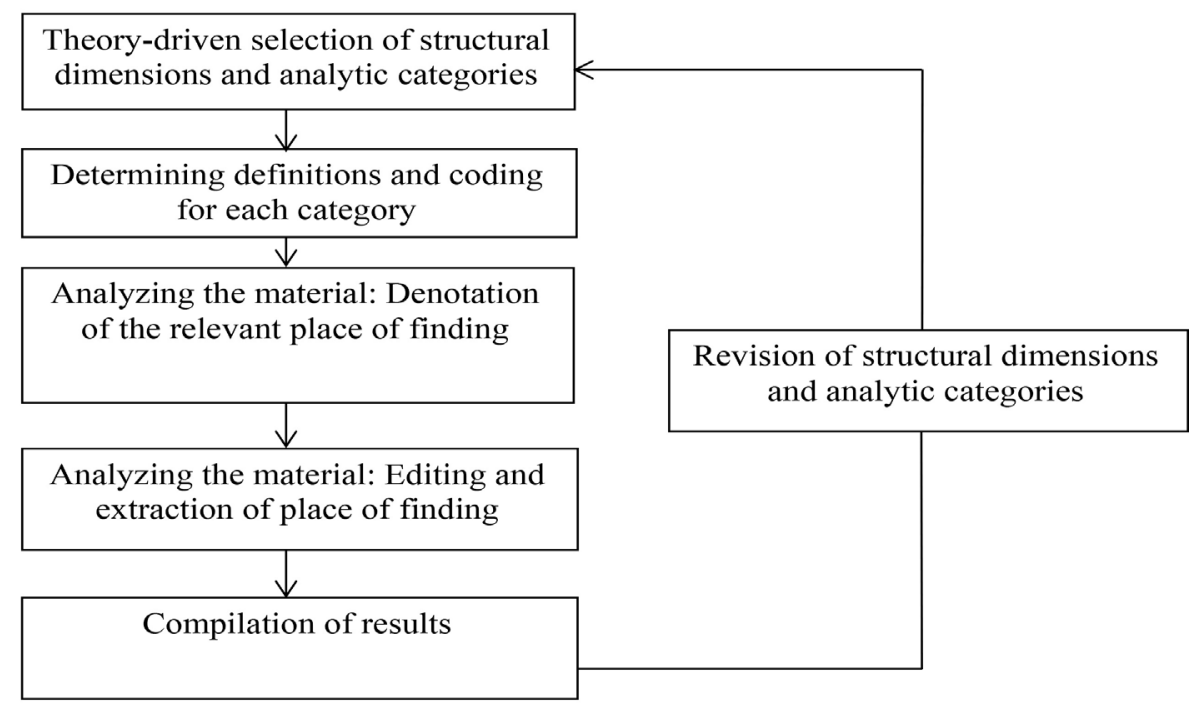

Figure 1: Research process concerning the content analysis of structures (Mayring, 2003, 120)

A structured keyword search was conducted in four major electronic databases: Elsevier (www.sciencedirect.com), Emerald (www.emeraldinsight.com), Springer (www. springerlink.com), and Wiley (www.wiley. com). The following queries were made in the title, abstract, and keywords fields: circular economy, business model, circularity, value, and alternations between them. All papers emerging from the search were also manually verified. Their titles and abstracts were read to ensure the paper fits the scope of the study. Of the 75 works identified, 51 were selected for inclusion in the final analysis. The central requirement was that the text explicitly or implicitly clarified the usage of the concepts of both the business model and circular economy. Afterwards, the level of elaboration of both terms determined relevance. Irrelevant papers were excluded from the analysis. If papers did not refer to either business models or circular economy in a sufficient degree (e.g. unclear usage of the business model concept or complete omission of the term circular economy), we considered them irrelevant.

After the initial selection, papers were arranged in the (author, date) format allowing for easy identification of the coded data. Such a coding method contributes to external validity as the research design is set up in a rigorous manner and transparently described in such an approach. With respect to other approaches to the systematic literature review in management studies, Mayring (2002) proposed to evaluate the collected materials through topic-specific structural dimensions and analytical categories. This approach allows a large number of records to be categorised and a framework establishing the main trends in circular business model studies is to be identified. Next, the papers were analysed against the derived categories. Each paper was coded against multiple categories or one single category depending on the focus of the paper. A frequency count of the categories was carried out and relevant issues were interpreted accordingly. A descriptive analysis was carried out to obtain a snapshot. Process content analysis was facilitated by the application of the NVivo software. The software's ability to systematically manage data aided the process of the thematic analysis to identify recurring themes and synthesize the results from this review. A detailed content analysis identified relevant issues in the circular business model and the results were interpreted accordingly to propose a conceptual framework (Figure 2). 


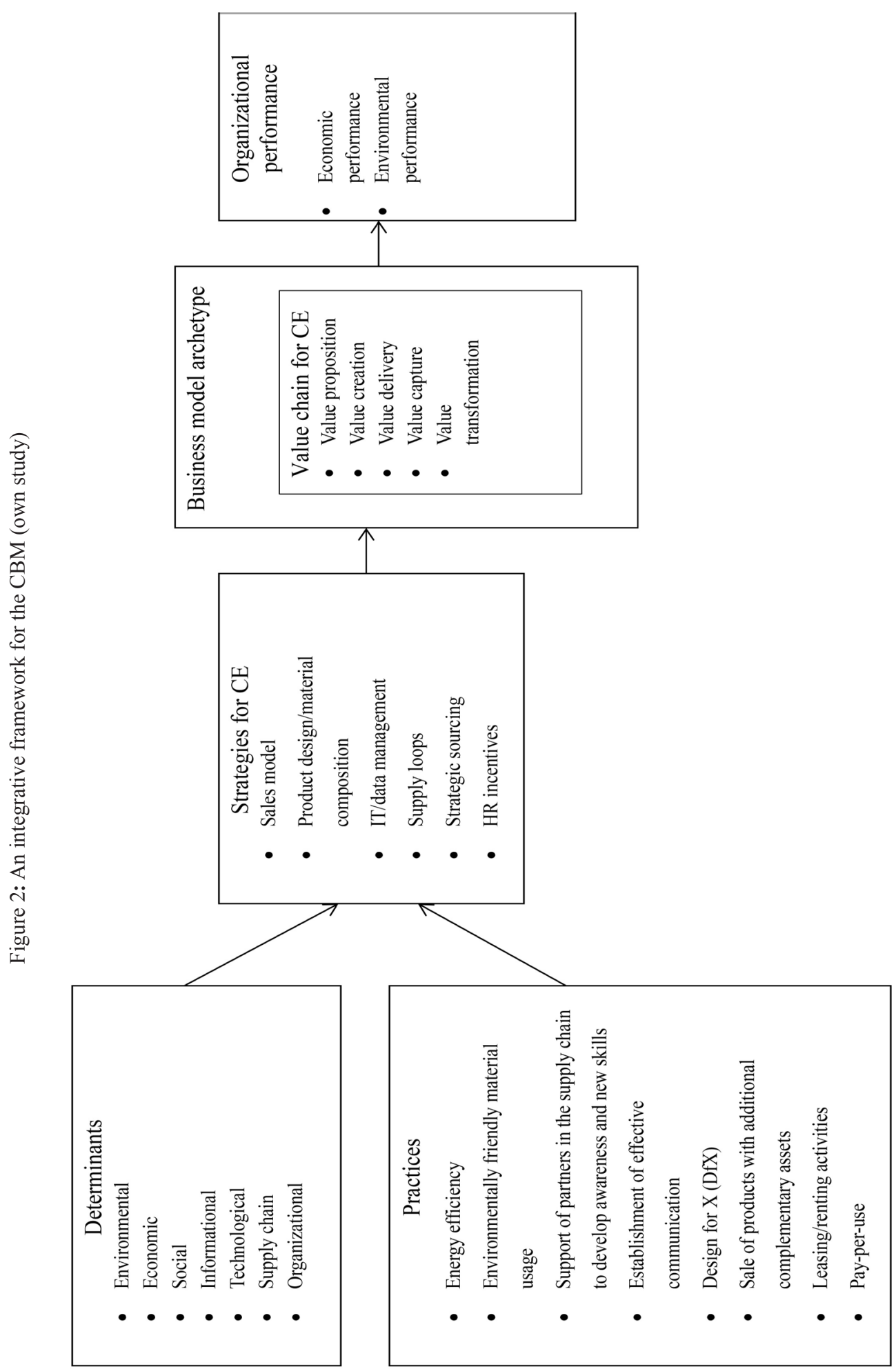




\section{Results and discussion}

\section{Development of Circular Business Models}

The integration of CE into business generates several challenges (Rizos et al., 2016; van Buren et al., 2016) resulting in a change of the approach to action and/ or changes in various subsystems of the organisation (Figure 3).

The development of the CBM requires alterations to how a business operates. It entails internal changes. The transition from the traditional business model to the CBM may occur in phases or as a leap from the inactive/defensive to active/strategic phase (Long et al., 2018). Mendoza et al. (2017) proposed a participative CBE framework to help to conceptualise and develop CE business innovations. The framework enables organisations to understand how they may implement CE by combining strategic business planning and operational tools. The CBM framework (Mendoza et al., 2017) comprises three main parts and ten iterative steps: envisioning a CE business (steps 1-3), designing what that business may look like (steps 4-6) and developing pathways for the implementation of the future business (steps 7-10). Kraaijenhagen et al. (2016) offered a practical 10 -step approach to how to initiate, lead and execute from pilot to circular businesses. Johannsdottir and McInerney (2018) developed a framework labelled
"Five C" which can be used as a reference point for BM development. It encompasses 5 stages: 1) commitment, 2) configuration, 3) core business, 4) communication and 5) continuous improvements. Stage 3 is the most significant of these because this is where the concentration on the core business occurs, which includes products, underwriting and risk management, and loss prevention. A similar methodological approach for service oriented firms was developed by Heyes et al. (2018). They indicate actions which may be undertaken in the framework of the individual phases of the Resolve model in order to progress to circular economy.

The adjustment of the BM model to the requirements of $\mathrm{CE}$ assumes various forms. Schaltegger et al. (2011) highlight the different forms: - adjustments, where only a small change is made, which does not include the value proposition: business model adoption where a business model is changed to match or mirror a competitor's changes; business model improvements where most elements of the business model are changed and improved; business model redesign where improvements mean that a new value proposition is developed. These stages relate well to the works of Van Tilburg et al. (2012) and Visser (2014), and similarly chart the various degrees or types

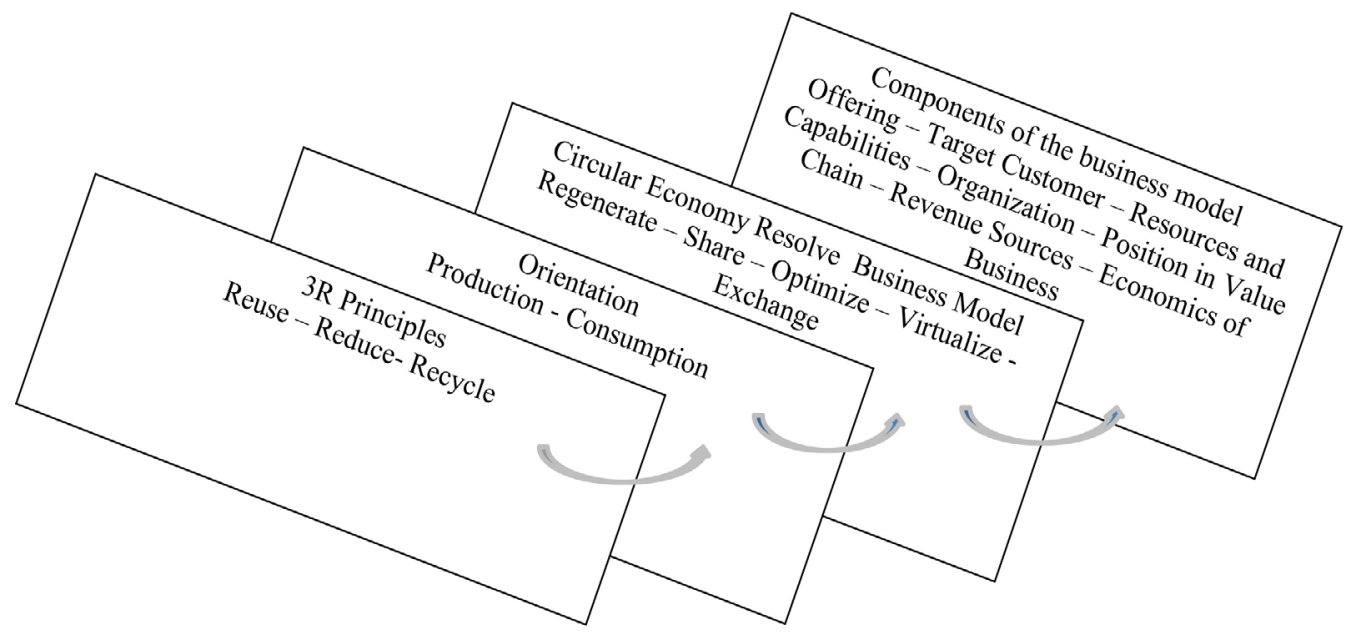

Figure 3: Direction of changes in the transition to the CBM (own study) 
of engagement, but this time, at the business model level. Lozano (2009) highlighted that the adjustment requires alterations to how a business operates, involving internal changes. A business model change which aims at the adjustment of the value chain, requires an implicit modification of several business model components.

For instance, the introduction of an added service to a product or an offer of leasing instead of a sale of a product induces a change in value proposition (Schaltegger et al., 2016). Tunn et al. (2019) indicated the need for changes in the framework of the following to be introduced: resource strategy, revenue model, consumer effort, and the objective for consumption level. As a consequence, changes in production (resource strategy and revenue model) and consumption (consumer effort and the objective for consumption) are required. Therefore, the issue revolves around production-related changes.

With regard to the operational dimension, four main modifications are required by companies to adapt or create a new business model to the existing needs of Circular Economy. In particular, these modifications require the implementation of reverse supply chain activities, a higher degree of cooperation within the supply chain, and a new value proposition for customers (Urbinati et al., 2017). The modification will result in changes in the value chain. These will be discussed in the next section.

\section{Value chain in the CBM}

We find that all elements (sub-processes) of the value chain are described in the literature although to different extents. The findings are discussed in detail below.

Value proposition represents which and how stakeholders' and customers' needs are addressed by the business or the network of businesses. In conventional, profit-oriented organisations, the success of the business is usually measured by its economic performance (Upward \& Jones, 2016). For circular thinking, the focus on economic success is too narrow and raises the need for a more holistic view of value. This integrates environmental objectives. Regarding value proposition, the core goal and vision of the organisation translates into offerings (products and services) needed to ensure revenue to compensate for costs emerging from environmental aspects. This includes the description of the needs and the offering of the bundle of products and services applied to address the target needs (Osterwalder \& Pigneur, 2010; Teece, 2010; Boons \& Lüdeke-Freund, 2013). The following factors may constitute the potential source of values (Schenkel et al., 2015):

- economic: cost reduction, new revenue source, risk reduction;

- environmental: the fulfilment of environmental objectives, the compliance with or anticipation of regulations;

- informational: feedback from consumer behavior, product life-cycle, product and process performance; and

- customer: higher customer satisfaction, corporate image and consumer loyalty enhancement.

Value proposition in circular economies should be in the offering of product-service systems (PSSs), which are, as suggested by Tukker and Tischner (2006), "a mix of tangible products and intangible services designed and combined so that they jointly are capable of fulfilling final customer needs". This denotes a change in the approach to the client- a shift from selling products to providing services generating multi-aspect value (i.e. economic, environmental) (Lay et al., 2009; Mont et al., 2006). Therefore, the value is no longer represented by the price, but by the number of functional units provided in the lifecycle.

Value creation addresses how value is created by the supply chain or how value is co-created in the value network. Designing circular business models requires a systemic point of view concerning products (Bakker et al., 2014). Companies need to collaborate 
with stakeholders to ensure reverse logistics. This, for example, allows them to maximise the value of products and materials (Kraaijenhagen et al., 2016). With regard to the methods of value creation, Lewandowski (2016), building on Osterwalder and Pigneur's (2010) business canvas model, adds two more dimensions for CE models - a take-back system (including channels and customer relations) and adoption factors (organisational capabilities and external factors).

Value delivery encompasses defining and managing aspects related to the relationship with stakeholders and communication, sales and distribution channels (Osterwalder \& Pigneur, 2010; Teece, 2010; Boons \& Lüdeke-Freund, 2013). Value delivery for circular business models incorporates multiple stakeholders in the innovation process as collaborative partners (Kraaijenhagen et al., 2016; Mentink, 2014; van Renswoude et al., 2015). These partners may differ from the "conventional" value chain. For Urbinati et al. (2017), value delivery emerges via the development of the value network and emergence of value interface. The value network defines the ways through which companies interact with their suppliers and reorganise their own internal activities, i.e. the key resources, activities, and upstream partners (Osterwalder \& Pigneur, 2013). From a circular perspective, this dimension aims at measuring what and how many of the circular operational practices are adopted in the internal activities of the company. The emergence of the value interface occurs when the organisation makes the compliance with the principles of circular economy visible to its customers. In this way, the value associated with the growth of customer awareness is generated. Ranta et al. (2018) draw attention to additional opportunities associated with value delivery, which emerge from takeback services. The supply of values may be driven by the system if the focal firm can acquire waste suitable for efficient recycling.

Value capture addresses how value is retained or recovered by businesses. In the traditional business model, value capture is expressed in the financial model, since results are mainly interpreted as the economic profit. The circular business model incorporates environmental results. The necessity of creating both economic and environmental value is indicated by Teece, 2010, Osterwalder and Pigneur, 2010, Boons and Lüdeke-Freund, 2013, Scheepens et al. 2016. Manninen et al. (2018) raised the problem of evaluating the environmental value propositions of $\mathrm{CE}$ business models. They indicated the environmental value propositions offer the efficient use of all natural resources, and reduce import dependence on natural resources, which pertain to the individual stages of the Resolve. They also discussed the environmental value proposition evaluation framework.

Circular business models must build upon traditional concepts and consider a long term transformational perspective as the sources of value. Therefore, the transformation of values assumes the long-term approach. It includes both infrastructural changes (Stubbs \& Cocklin, 2008) and changes in social expectations. The transformation of value highlights changes emerging in the business model as a result of the adaptation of the model to changes in the environment.

We take the stand that there exists a direct relationship between the value chain and key challenges of implementing the CBM. These are classified under cultural aspects, risk, stakeholder relationships, internal processes (Sousa-Zomer et al., 2018). Figure 4 outlines the value chain in the CBM and main challenges to be overcome. 


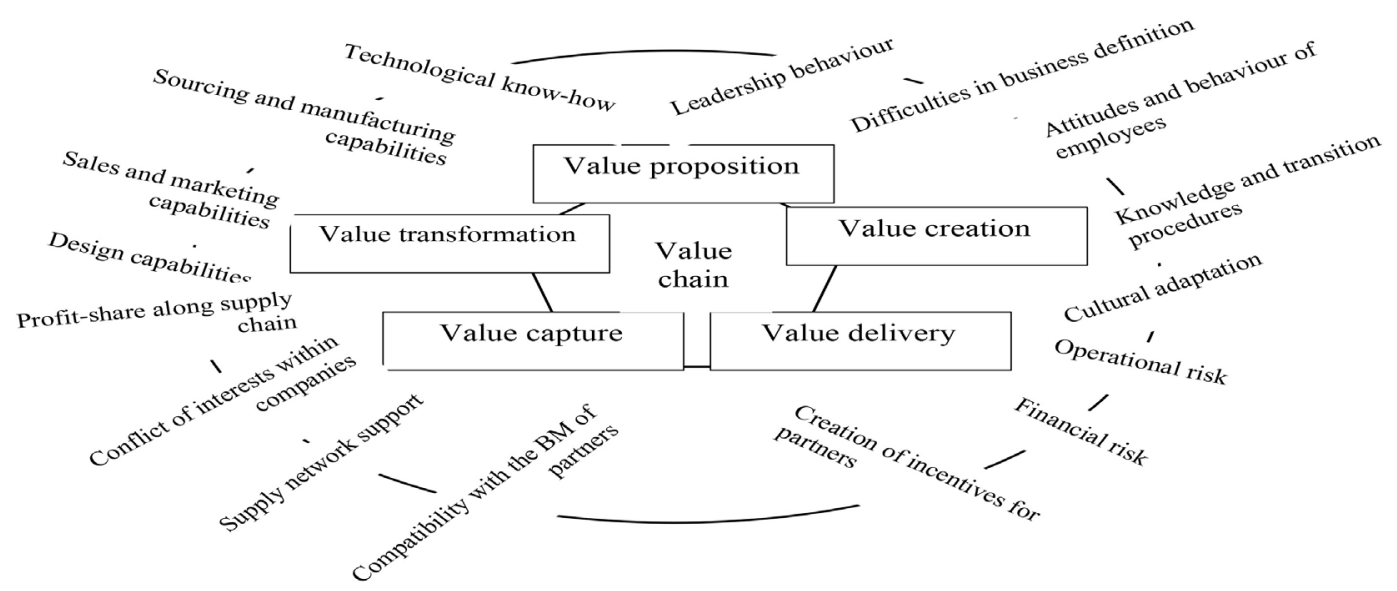

Figure 4: Associating the value chain and main challenges to create a CBM

Source: own proposition with the use of Stewart et al. (2018) and Sousa-Zomer et al. (2018)

\section{Archetypes of the CBM}

Circular business models adapt to the context organisations operate in Guldmann, 2016. As a consequence, different circular business models often operate in parallel (Whalen, 2017). They may be classified in several ways, for example, through their environmental strategies including slowing, closing and narrowing resource loops ( Bocken et al., 2016), or in the following six categories: short cycle, long cycle, cascading, pure circles, digitization, and produce on demand (Wolde, 2016). Bocken et al. (2014) introduced eight sustainable business model archetypes, described as businesses that a) maximise material and energy efficiency, b) create value from waste, c) substitute with renewables and natural processes, d) deliver functionality rather than ownership e) adopt a stewardship role, f) encourage sufficiency, g) re-purpose the business for society/ environment, and h) develop scale-up solutions. The modification of these archetypes as a result of their empirical verification is postulated by D'Amato et al. (2018). They distinguish the following models: material and energy efficiency, waste value, replace fossil with natural resources, repurpose for society, scale-up solutions, functionality instead of ownership, social and environmental stewardship, sufficiency. Due to the direction of influence, the taxonomy of Urbinati et al. (2017) suggests three available modes: downstream circular (altering value capture and delivery through new revenue schemes and customer interface, e.g. pay-per-use models), upstream circular (changing value creation systems, e.g. reverse logistics), or fully circular (combining upstream and downstream principles). Similarly, to the pro-ecological strategies, the "fully circular" business models are more impactful. Other authors suggest alternative archetypes, i.e.: recycle, reduce and share, remanufacture, eco-design, biodegradability, classic longlife model (Bakker et al., 2014; Mont, 2008), innovation platforms (Leipold \& Petit-Boix, 2018), sufficiency encouraged (Gnoni et al., 2017; Moreno et al., 2016; Riisgaard et al., 2016) and access and performance model (Cohen \& Munoz, 2016; Nußholz, 2017 2018; Planing, 2018; Weetman, 2016).

Authors are inclined to systematize several propositions of the CBM The propositions indicate that, first, the established business models such as recycling or replacing fossil resources with bio-based resources are overrepresented, while less established business models such as sharing or leasing are promoted much less (Leipold \& Petit-Boix, 2018). Secondly, less attention is assigned to more innovative approaches which aim to change the way how products and services are provided 
to consumers (De los Rios \& Charnley, 2017). Therefore, new designer archetypes are proposed which are not exclusive to specific products or business models: sharing platforms, products as services, product life extension (provision of consumables, or high-end and reuse or refurbish and upgrade), material recovery, circular supplies (Ritala et al., 2018; Yip \& Bocken, 2018; Palomares-Aguirre et al., 2018).

Considering the assessment of the proposed models (see Lüdeke-Freund et al., 2019), it should be stated that repair and maintenance models" (e.g., building on repair (Kiørboe et al., 2015), product life extension (Accenture, 2014), classic long life model (Bocken et al., 2016)) require organisations to have customer centric services, corresponding forward and reverse logistics, up to date product expertise, and fast learning and problem solving capabilities. The strengths of these models are gaining value from different forms of product life extension, focusing on offering superior product experience. As a result, the need for the customer to buy a new product is reduced. The limitation is ambiguous revenue models in the long run. In particular, difficulties relate to pricing policy, e.g. whether organisations should increase the price of a product because of long-life service or introduce additional payments for an additional service exceeding a certain period. The second group of models "reuse and redistribution" (e.g., reuse/ refurbish/maintain/redistribute/next life sales (Planing, 2015), reuse (Kiørboe et al., 2015), product life extension (Accenture, 2014)) are about offering access to used products, which might include slight enhancements or modifications, and creating a market place. The strength of these models is that manufacturers offer reuse and redistribution services; new revenue sources can be developed by re-selling a product several times. Nevertheless, these models require that used products flow back to the provider, which means that organisation depends on customer returns. It must also create reverse logistics channels. "Refurbishment and remanufacturing business models" have similar weaknesses (e.g., upgrading (Planing, 2015), product life extension (Accenture, 2014). Most publications argue that reduced or at least slowed streams of waste to landfills, reduced carbon emissions, and spared natural resources are the most important sustainability contributions of these models (Vogtlander et al., 2017). However, others argue that value creation potential of refurbishment and remanufacturing is based on access to goods and components that can be resold, which limits their use. Another group of business models constitutes "recycling models" (e.g., building on closed loop production, rematerialization (Clinton \& Whisnant, 2014), recycling and waste management (Kiørboe et al., 2015). They are based on inputs offered by waste collectors/processors. The existence of these models results from the need to recycle, hence their development can be expected in the future. On the other hand, recycling business models are very diverse - country, city, or even neighbourhood specific, and involve a diverse set of actors. For this reason, their simple "copying" is not possible. To a large extent, their effectiveness also depends on economic factors, i.e. profits from recycling. The last group of circular business models are "cascading and repurposing models" (e.g., multiple cash flows/ multiple revenues (Pauli, 2010). According to Lüdeke-Freund et al. (2019), cascading could offer a variety of green inputs (within IS relationships) and products (offered to consumers). The benefits of such models should be comparable to those of recycling. Their efficiency and effectiveness might even be higher due to the possibility of tightening and adding further cascades, while complexity of coordinating multiple value propositions, material cycles, and related logistics is the limitation.

\section{Circular strategies for organisations}

Strategies for $\mathrm{CE}$ are proposed on two main levels. The first refers primarily to the macro level in which $\mathrm{CE}$ is fostered at an administrative level such as national, regional, or city. Another aspect concerns the micro-level analysis, which incorporates circular strategies into the field of strategic management. Circular strategies have the potential to save embodied energy and reduce 
resource intensive primary production and waste generation by first slowing resource loops and then closing resource loops (Stahel, 1994; Bocken et al., 2016). Closing resource loops refers to material recovery once the end-of life is irreversibly reached. Slowing resource loops refers to prolonging the useful life of products and parts. This can be achieved through circular strategies involving design for longevity, repair, refurbishment, and remanufacturing to prolong the useful life of resources. The most comprehensive classification of strategies for CE was developed by Laubscher and Marinelli (2014). It encompasses the following:

- A sales model which is shifting from selling volumes of products to selling services and taking back products at the end of their useful life. The strategy pertains to the offering of product-service systems (PSSs), which are, as suggested by Tukker and Tischner (2006), "a mix of tangible products and intangible services designed and combined so that they jointly are capable of fulfilling final customer needs". Product-services can be delineated into three categories: product-, use- and result-oriented business models. Use- and result-oriented business models possess the greatest potential influence upon ecological impacts (Tukker, 2004; Tukker \& Tischner, 2006). Iung and Levrat (2014) describe and analyse the role of maintenance in the PSS offers as a way to guarantee service continuity towards circular economy paths. A similar observation was made by Johansson et al. (2016) and Gnoni et al. (2017)

- Product design/material composition to be reused for high quality products, components and materials. The role of design has been widely acknowledged as DfX practices by many authors (Design for remanufacturing and reuse, Df recycling, Df environment) (De los Rios \& Charnley, 2017; Moreno et al., 2016). It is believed that organisations which implement practices of DfX have a high (or mediumhigh) degree of circularity (Urbinati et al., 2017);
- IT/data management where the strategy pertains to leveraging IT to keep track of products in order to optimise resources, including logistics of the reverse supply chain. Technology enables companies to optimise logistics, reduce the costs of storing and shipping. The use of ICT and sensor technologies has also been noted as a key enabler of circular business models (Tukker, 2015; Winans et al., 2017)

- The supply loops in which organisations need to add and manage the activities of the reverse supply chain, i.e. the reverse logistics, to the typical activities of the forward supply chain, i.e. planning, purchasing, production, distribution. The differences in the supply chains of conventional and circular business models stem from the necessary closing, slowing, and narrowing of material and energy flows. As a consequence, the Circular Supply Chain Management (CSCM) emerges. It constitutes the configuration and coordination of the organisational functions within and across business units and organisations to close, slow, intensify, narrow, and dematerialize material and energy loops in order to minimise resource input into and waste and emission leakage out of the system, improve its operative effectiveness and efficiency and generate competitive advantages (Geissdoerfer $\mathrm{et}$ al., 2018). Since cooperation across actors in circular business models goes beyond mere supplier-buyer transactions and is likely to occur outside the actors' core activities, the value network-centered approach of the business model seems relevant (Singh \& Ordoñez, 2016). Organisational cooperation pertains to all stakeholders. Establishing strategic partnerships with others can expand potential distribution channels and help minimise costs. Therefore, building long-term partnerships with stakeholders to enable take-back and value co-creation is critical for creating and capturing value and for establishing a viable business strategy (Veleva \& Bodkin, 2018) 
- Strategic sourcing is the collaboration between procurers and suppliers that can lead to reductions in raw materials' utilisation and waste generation, whilst promoting the development of circular business models with improved contribution to the achievement of circular economy (Witjes and Lozano, 2016). The ability of companies to develop inter-organisational cooperation is also necessary (Ruggieri et al., 2016). The suppliers and partners provide additional knowledge needed to be implemented in the business (Sousa-Zomer et al., 2018). During the collaboration in the process between procurement and business models for CE, a company can gain experience in defining product or service specifications to close loops and optimise the use of resources

- $\quad \mathrm{HR} /$ incentive is a strategy in developing incentives for a cultural and competence shift towards the adoption of circular business models. Boons and Lüdeke-Freund (2013) discussed the role of normative aspects, such as leadership and organisational culture, in enabling the transition towards the sustainability-oriented BM. Similar considerations can be made with regard to $\mathrm{CE}$ and HR practices pertaining to, for e.g. the acquisition of skills. De los Rios and Charnley (2017) indicated the skills necessary to create products for closed loops. These include for understanding logistics and distribution processes, understanding the service experience and how to design services, the assessment of material, physical and chemical properties, understanding the engineering functions of the product, understanding failure mode and maintenance procedures.

\section{Determinants of CBM development}

Linder and Williander (2015) distinguished several factors influencing the implementation of the CBM i.e. the typologies of customers, the technological expertise of companies, the portfolio of products, the operational risks of cannibalisation, fashion vulnerability, the capital tied up and the incentives for partners. Levanen et al. (2018) indicated the significance of institutional environment for shaping business model elements. They outlined how institutions' regulatory and technological development, the take-back system for waste, additional costs for a recycler, and Responsible Recycling Standard, influence value proposition, creation, and capture. Gnoni et al. (2017) included the following in the group of external determinants: provision of the economic sustainability for the producer, the introduction of tax incentives and awareness among users towards the topics of sustainability and CE. Jabbour et al. (2017) highlighted the necessary integration of largescale data.

It is acknowledged that, apart from the external factors, internal ones also play an important role in the development of a business model (Birkin \& Polesie, Lewis, 2009). Randles and Laasch (2016) and Boons and Lüdeke-Freund (2013), discussed the role of normative aspects, such as leadership and organisational culture, in enabling the transition towards a sustainabilityoriented BMI. With regard to circular economy, Kraaijenhagen et al. (2016) incorporated change management activities in their cyclical process for organisational transformation. The issue of leadership is associated with it. However, it is not well embedded in the CBM scholarship. Wesselink et al., (2017) suggested that leadership matters in pro-environmental behaviour, and can play an important role in business models. Bocken et al. (2018) focused on the process and role of business model experimentation. They developed and applied a circular business experimentation framework.

Regarding the internal resources, a range of organisational capabilities necessary for implementing the circular business was developed in some papers. Sousa-Zomer et al. (2018) drew attention to organisational capabilities associated with different functions (marketing, R\&D, purchasing, sales, service, and legal). De los Rios and Charnley (2017) enumerated a set of skills, including service 
experience, understanding user expectations and the perception of value, understanding product wear by use, assessing material properties, understanding processes for reverse logistics and re-manufacturing. Lacy et al. (2014) also emphasised the significance of competences associated with external processes. It should be noted that although multiple papers developed specific capabilities, the full implementation of the CBM occurred via the integration of multiple capabilities. Results obtained by Ünal et al. (2018) indicated that managers willing to embrace circular economy principles should leverage the managerial practices (both the value chain and the bottom line) to aid the transition of their companies towards circularity. They suggested that these ought to be classified into the following: energy-efficiency-driven practices to reduce emissions and environmental footprint, environmentally friendly material usage-driven practices, support of all partners to develop awareness and new skills, the establishment of effective communications with suppliers, retailers, the sale of products with additional complementary assets, Design for X (DfX) practices. Souse-Zomer et al. (2018) focus upon practices related to cleaner production and optimising the performance and efficiency of processes. According to the ReSOLVE framework, actions that organisations can take in order to promote the transition to circular economy may refer to: Regenerate, Share, Optimize, Loop, Virtualize and Exchange (The Ellen MacArthur Foundation, 2015; Table 1). Stål and Corvellec (2018) pointed to other factors (outsourcing and internal separation).

The review of literature confirms that some authors combine the internal and external determinants of developing a circular business model. For example, Rizos et al. (2016) highlighted the significance of capital, administrative burden (new practices can be considered complex and entail more complicated and costly management and planning processes), company environmental culture, legislation, information, technical and technological knowhow, and support from the demand and supply network. Liu and Bai (2014) stated that CBM determinants include: the firm's structure (management systems, long-term investments),

Table 1: CE supporting actions included in the Resolve model

\begin{tabular}{ll}
\hline Regenerate & $\begin{array}{l}\text { Description } \\
\text { flions focus on a shift to renewable energy and materials. Biological cycles circulate the } \\
\text { materials for other chains (Seghetta et al., 2016). }\end{array}$ \\
\hline Share & $\begin{array}{l}\text { Activities in the field of shared economy in which individuals share goods and assets and } \\
\text { ownership loses importance. Products are designed to last longer, and maintenance focuses } \\
\text { on extending their life. Products are shared so that more users can use them (Bakker et al., } \\
\text { 2014; Bonciu \& Balgar, 2016). }\end{array}$ \\
\hline Optimise & $\begin{array}{l}\text { Organisations use digital manufacturing technologies and remote steering to reduce waste in } \\
\text { production systems and supply chains (Cattelan Nobre et al., 2017). }\end{array}$ \\
\hline Loop & $\begin{array}{l}\text { Organisations use biological and technical cycles. Biological cycles can recapture the value } \\
\text { of organic waste. Technical cycles can restore the value of post-consumption products and } \\
\text { packaging through reuse, remanufacturing, repair. }\end{array}$ \\
\hline Virtualise & $\begin{array}{l}\text { Organisations replace physical products with virtual and dematerialised products. Features: } \\
\text { smart connected products, linking with the internet of things, enable data gathering for the } \\
\text { technical cycle (Bigano et al., 2016). }\end{array}$ \\
\hline Exchange & \begin{tabular}{l} 
Transform old and non-renewable goods into renewable ones (Delgado-Aguilar et al., 2015). \\
\hline
\end{tabular}
\end{tabular}


contextual factors (government regulations, uncertainty regarding the marketplace), and cultural factors (leadership issues, risk aversion). Tura et al. (2019) classified these into seven distinct categories of environmental, economic, social, institutional, technological and informational, supply chain, and organisational factors.

\section{Conclusion}

The overall contribution of the paper is that it reviews the literature verging upon business models and circular economy and provides an in-depth understanding of many dimensions of circular business models. Therefore, the first contribution of this research is the collection and review of 51 related papers in a systematic manner. This serves as a basis for summarising the arguments with in this field of research. The proposed framework (Figure 2) is then used for a systematic evaluation of the respective literature, offering the second contribution of the paper. The framework is linked to the body of literature analysed on the basis of a quantitative content analysis approach.

Based on the existing literature, we argue that the adoption of principles of Circular Economy requires organisations to adapt their business models or create new ones. It stems from a new approach where the linear flow of resources - products - waste (typical for traditional business models) is replaced by the new pattern, supplementing the sequence with renewable resources.

The present study has enabled several conclusions to be drawn. First, while there have been some papers devoted to circular business models, the issue still remains somewhat ambiguous, resulting in many different interpretations across different contextual settings. The concepts and solutions discussed in the framework of the individual surveyed areas are becoming more heterogeneous and rely on multiple theories. This is not surprising given the original concept of $\mathrm{CE}$, but it still leaves room for further research. In addition, the extension of the business model conceptualisation to include the field of circular business models remains in its early stages of development. Whilst there is a general agreement that researchers should embrace the idea of circular economy, its operationalisation in the form of business models remains challenging.

Secondly, the identified circular business models vary with regard to the source of value and complexity. The identified models largely focused on traditional sustainability perspectives, such as maximising material and energy efficiency. As a consequence, CBM archetypes offered herein derive from the sustainability-oriented $\mathrm{BM}$ or duplicate sustainable business models (SBM). In our opinion, the literature lacks models pertaining directly to CE. At the same time, the existence of different propositions of SBM archetypes, without $\mathrm{CE}$ principles being taken into account, might hinder the consolidation of knowledge in the field.

Thirdly, the review shows that most of scholars' interest is focused on the subprocesses of the value chain. Studies devoted to value proposition are dominant. However, those pertaining to value transition are missing. Some authors downright omit the sub-process. As a consequence, practices aimed at reducing environmental impact and at promoting a more efficient use of natural resources are widely investigated by scholars. Conversely, those aiming at the introduction of new technological solutions or reformulating value transition still remain marginal (Merli et al., 2018).

Fourthly, the results of studies emphasise the importance of a gradual evolution in the business models of organisations and their transition to circularity. Such changes seem to have much in common with organisational changes in general. These cannot be made spontaneously or ad-hoc, but ought to constitute an element of a broader plan for the transformation of the organisation towards CE.

Our framework is especially useful for supporting organisations willing to adopt a 
circular business model or for organisations which seek ways to enhance their level of circularity. It points to elements which ought to be considered in the process of BM transformation. The conceptual framework highlights practices and enablers which exert an impact on the value chain. Circular strategies constitute an intermediate variable here. Against the existing CBM analyses, the framework proposed in this paper applies a multidimensional perspective, thereby providing more insights into the managerial issues, and its linkage to performance.

The major limitation of this paper is the selection of keywords, which might have limited the inclusion of potential papers contributing to the topic. Such conceptualisations based on a literature review are burdened with previous research thinking and might not be forward looking. The second limitation is the content analysis conducted exclusively in the selected topics. Further analyses may be conducted with the use of additional constructs missing in the present study.

Limitations of the study may serve as a baseline for improving and stimulating future research. First, the scope of the research may be expanded not only to academic literature, but also to grey literature. The expansion of the knowledge base to incorporate the descriptions of organisations which have already implemented CE seems worthwhile. Another future need is the development of quantitative methods to support decision-making. Despite the qualitative tools (Annex), quantitative indicators and tools to assess different concepts of the BM economically and environmentally are missing. The types of measures to be applied for the CBM are worth considering. Finally, the interactions between existing business models and the co-existence of various models remain largely unexplored. Further considerations of interactions between the existing business models and the impact of new, circular business models could be productively studied in the future. For instance, how can existing organisations add circular business models to their business model portfolio? What types of changes in the hitherto models will the addition of new sources of value require? We posit that there exists a great potential for multidisciplinary research to build on during the next decades with the objective to surpass the current understanding of CBMs. A deeper exploration of this novel research area offers great opportunities for multi-method and multidisciplinary contributions.

\section{Acknowledgements}

\section{References}

Accenture (2014). Circular advantage. Innovative business models and technologies to create value in a world without limits to growth. London, UK: Accenture.

Aminoff, A., Valkokari, K., Antikainen, M., \& Kettunen, O. (2017). Exploring disruptive business model innovation for the circular eEconomy. Sustainable Design and Manufacturing, 1, 525-36.

Antikainen, M., \& Valkokari, K. (2016). A framework for sustainable circular business model innovation. Journal Technology Innovation Management Review, 6(7), 5-12.

Bakker, C., Wang, F., Huisman, J., \& Den Hollander, M. (2014). Products that go round: Exploring product life extension through design. Journal of Cleaner Production, 69, 10-16.

Barney, J. B., Wright, M., \& Ketchen, D. J. (2001). The resource based view of the firm: Ten years after 1991. Journal of Management, 27, 625-643.

Bigano, A., Sniegocki, A., \& Zotti, J. (2016). Policies for a more dematerialized eu economy. Theoretical underpinnings, political context and expected feasibility. Sustainability, 8, 1-22.

Bocken, N. M. P., de Pauw, I., Bakker, C., \& van der Grinten, B. (2016). Product design and business model strategies for a 
circular economy. Journal of Industrial and Production Engineering, 33(5), 308-20.

Bocken, N., Short, S., Rana, P., \& Evans, S. (2013). A value mapping tool for sustainable business modelling. Corporate Governance, 13(5), 482-497.

Bocken, N. M. P., Schuit, C. S. C., \& Kraaijenhagen, C. (2018). Experimenting with a circular business model: Lessons from eight cases. Environmental Innovation and Societal Transitions, 28, 79-95.

Bocken, N. M. P., Short, S. W., Rana, P., \& Evans, S. (2014). A literature and practice review to develop sustainable business model archetypes. Journal of Cleaner Production, 65, 42-56.

Bonciu, F., \& Balgar, A. C. (2016). Sharing economy as a contributor to sustainable growth. An EU perspective. Romanian Journal of European Affairs, 16, 36-45.

Boons, F., \& Lüdeke-Freund, F. (2013). Business models for sustainable innovation: State-ofthe-art and steps towards a research agenda. Journal of Cleaner Production, 45, 9-19.

Boulding, K. E. (1966). The economics of the coming spaceship earth. In Jarrett, H., (Ed.), Environmental quality in a growing economy. Resources for the Future/Johns Hopkins University Press, Baltimore, 3-14.

Braungart, M., Mcdonough,W., \& Bollinger, A. (2007). Cradle-to-cradle design: Creatinghealthy emissions e a strategy for eco-effective product and system design. Journal of Cleaner Production, 15(13-14), 1337-1348.

Bryant, R. L., \& Wilson, G.A. (1998). Rethinking environmental management. Progress in Human Geography, 22, 321-343.

Cattelan Nobre, G., Tavares, B. E., \& Tavares, E. (2017). Scientific literature analysis on big data and internet of things applications on circular economy: A bibliometric study. Scientometrics. CIRAIG (International Reference Centre for the Life Cycle of Products Processes and Services). (2015).
Circular economy: A critical literature review of concepts. Canada, Montreal.

Clauss, T. (2016). Measuring business model innovation: Conceptualization, scale development and proof of performance. $R \& D$ Management, 1-19.

Clinton, L., \& Whisnant, R. (2014). Model behavior-20 business model innovations for sustainability. London: SustainAbility.

Cohen, B., \& Munoz, P. (2016). Sharing cities and sustainable consumption and production: Towards an integrated framework. Journal of Cleaner Production, 134, 87-97.

D’Amato, D., Veijonaho, S., \& Toppinen, A. (2018). Towards sustainability? Forestbased circular bioeconomy business models in Finnish SMEs. Forest Policy and Economics.

De los Rios, I. C., \& Charnley, F. J. S. (2017). Skills and capabilities for a sustainable and circular economy: The changing role of design. Journal of Cleaner Production, 160, 109-122.

Delgado-Aguilar, M., Tarres, Q., Pelach, M._A., Mutje, P., \& Fullana-I-Palmer, P. (2015). Are cellulose nanofibers a solution for a more circular economy of paper products? Environmental Science \& Technology, 49, 12206-12213.

Dong, L., Fujita, T., Dai, M., Geng, Y., Ren, J., Fujii, M., Wang, Y., \& Ohnishi, S. (2016). Towards preventative eco-industrial development: an industrial and urban symbiosis case in one typical industrial city in China. Journal of Cleaner Production, 114, 387-400.

Du, H., Li, B., \& Ding, H. (2009). Circular economy and regional economic development in the Zhejiang province, Southern China. International Journal of Environmental Technology Manag. 11, 319.

EMAF (Ellen MacArthur Foundation). (2015). Growth within: A circular economy vision for a competitive Europe. London. 
EMAF (Ellen MacArthur Foundation). (2013). Towards the circular economy. London.

Geissdoerfer, M., et al. (2017). The circular economy - a new sustainability paradigm? Journal of Cleaner Production, 143, 757768.

Geissdoerfer, M., Morioka, S. N., de Carvalho, M., \& Evans, S. (2018). Business models and supply chains for the circular economy. Journal of Cleaner Production, 190, 712721.

Geng, Y., Zhu, Q., Doberstein, B., \& Fujita, T. (2009). Implementing China's circular economy concept at the regional level: a review of progress in Dalian, China. Waste Management, 29, 996-1002.

Gnoni, M. G., Mossa, G., Mummolo, G., Tornese, F., \& Verriello, F. (2017). Supporting circular economy through use-based business models: The washing machines case. Procedia CIRP, 64, 49 - 54.

Hart, S. L. (1997). Beyond greening: Strategies for a sustainable world. Harvard Business Review, 75, 66-76.

Heyes, G., Sharmina, M., Mendoza, J. M., Gallego-Schmid, A., \& Azapagic, A. (2018). Developing and implementing circular economy business models in service-oriented technology companies. Journal of Cleaner Production, 177, 621632.

Hobson, K., \& Lynch, N. (2016). Diversifying and de-growing the circular economy: Radical social transformation in a resourcescarce world. Futures, 82, 15-25.

Integrating backcasting and eco-design for the circular economy: The BECE framework. Journal of Industrial Ecology, 21(3), 526544.

Iung, B., \& Levrat, E. (2014). Advanced maintenance services for promoting sustainability. Procedia CIRP, 22, 15-22.

Jabbour, C. J. C., Jabbour, A. B., Sarkis, J., \& Filho, M. G. (2017). Unlocking the circular economy through new business models based on large-scale data: An integrative framework and research agenda. Technological Forecasting \& Social Change.

Jauch, L., Osborn, R., \& Martin, T. (1980). Structured content analysis of cases: A complementary method for organizational research. Academy of Management Review, 5(4), 517-525.

Johannsdottir, L., \& McInerney, C. (2018). Developing and using a Five $\mathrm{C}$ framework for implementing environmental sustainability strategies: A case study of Nordic insurers. Journal of Cleaner Production, 183(10), 1252-1263.

Johansson, C., Elfsberg, J., Larsson, T. C., Frank, M., Leifer, L. J., Nilsson, N., \& Söderberg, V. (2016). Urban mining as a case for PSS. Procedia CIRP, 47, 460-465.

Kiørboe, N., Sramkova, H., \& Krarup, M. (2015). Moving towards a circular economy-Successful Nordic business models. Copenhagen: Nordic Council of Ministers.

Korhonen, J., Honkasalo, A., \& Seppala, J. (2018). Circular economy: The concept and its limitations. Ecological Economics, 143, 37-46.

Kraaijenhagen, C., Van Oppen, C., \& Bocken, N. (2016). Circular business collaborate and circulate. Circular collaboration. Amersfoort, The Netherlands. Available at circularcollaboration.com.

Lacy, P., Keeble, J., McNamara, R., Rutqvist, J., Haglund, T., Cui, M., Cooper, A., Pettersson, C., Kevin, E., \& Buddemeier, P. (2014). Circular Advantage: Innovative Business Models and Technologies to Create Value in a World Without Limits to Growth. https://www.accenture. com/t20150523T053139__w__/usen/_ acnmedia/Accenture/Co

nversion-Assets/DotCom/Documents/Global/ PDF/Strategy_6/Accenture-Circular- 
Advantage-Innovative-Business-ModelsTechnologies-Value-Growth.pdf.

Laubscher, M., \& Marinelli, T. (2014). Integration of circular economy in business. In Proceedings of the Conference; Going Green e Care Innovation 2014. Vienna, Austria, 17-20 November.

Leipold, S., \& Petit-Boix, A. (2018). The circular economy and the bio-based sector perspectives of European and German stakeholders. Journal of Cleaner Production, 201, 1125-1137.

Lewandowski, M. (2016). Designing the business models for circular economy towards the conceptual framework. Sustainability, 8, 1-28.

Lieder, M., \& Rashid, A., (2016). Towards circular economy implementation: A comprehensive review in context of manufacturing industry. Journal of Cleaner Production, 115, 36-51.

Linder, M., \& Williander, M. (2015). Circular business model innovation: Inherent uncertainties. Business Strategy \& Environment, 26(2), 182-196.

Liu, Y., \& Bai, Y. (2014). An exploration of firms' awareness and behavior of developing circular economy: An empirical research in China. Resources Conservation and Recycling, 87, 145-152.

Long, T. B., Looijen, A., \& Blok, V. (2018). Critical success factors for the transition to business models for sustainability in the food and beverage industry in The Netherlands. Journal of Cleaner Production, 175, 82-95.

Lozano, R. (2009). Orchestrating organisational change for corporate sustainability: Strategies to overcome resistance to change and to facilitate institutionalization. Cardiff University Business School. University of Cardiff, Cardiff.

Lüdeke-Freund, F. (2010). Towards a conceptual framework of business models for sustainability. In Knowledge Collaboration \& Learning for Sustainable Innovation
ERSCP-EMSU Conference, Delft, The Netherlands, pp.1-28.

Lüdeke-Freund, F., \& Dembek, K. (2017). Sustainable business model research and practice: Emerging field or passing fancy? Journal of Cleaner Production, 168, 16681678.

Lüdeke-Freund, F., Gold, S., \& Bocken, N. M. P. (2019). A review and typology of circular economy business model patterns. Journal of Industrial Ecology, 23(1), 36-61.

Manninen, K., Koskela, S., Antikainen, R., Bocken, N., Dahlbo, H., \& Aminoff, A. (2018). Do circular economy business models capture intended environmental value propositions? Journal of Cleaner Production, 171, 413-422.

Mathews, J. A., \& Tan, H. (2011). Progress towards a circular economy in China: The drivers (and inhibitors) of eco-industrial initiative. Journal of Industrial Ecology, $15,435-457$

Mayring, P. (2003). QualitativeInhalt analyse - Grundlagen und Techniken (Qualitative Content Analysis - Basics and Techniques). Weinheim, Beltz, Verlag.

Mendoza, J. M. F., Sharmina, M., GallegoSchmid, A., Heyes, G., \& Azapagic, A. (2017). Integrating backcasting and ecodesign for the circular economy: The BECE framework. Journal of Industrial Ecology, 21(3), 526-544.

Mentink, B. S. (2014). Circular Business Model Innovation A process framework and a tool for business model innovation in a circular economy. Master Thesis. Delft University of Technology and Leiden University.

Merli, R., Preziosi, M., \& Acampora, A. (2018). How do scholars approach the circular economy? A systematic literature review. Journal of Cleaner Production, 178, 703722.

Mihelcic, J. R., et al. (2003). Sustainability science and engineering: The emergence 
of a new metadiscipline. Environmental Science \& Technology, 37, 5314-5324.

Mont, O. (2008). Innovative approaches to optimising design and use of durable consumer goods. International Journal of Product Development, 6, 227.

Moreno, M., De los Rios, C., Rowe, Z., \& Charnley, F. (2016). A conceptual framework for circular design. Sustainability, 8(9), $1-15$.

Murray, A., Skene, K., \& Haynes, K. (2015). The circular economy: An interdisciplinary exploration of the concept and application in a global context. Journal of Business Ethics, 140(3), 369-380.

Naustdalslid, J. (2017). Circular economy in China - the environmental dimension of the harmonious society. International Journal of Sustainable Development \& World Ecology, 21(4), 303-313.

Nußholz, J. L. K. (2018). A circular business model mapping tool for creating value from prolonged product lifetime and closed material loops. Journal of Cleaner Production, 197, 185-194.

Ormazabal, M., Prieto-Sandoval, V., Jaca, C., \& Santos, J., (2016). An overview of the circular economy among SMEs in the Basque Country: A multiple case study. Journal of Industrial Engineering \& Management, 9, 1047-1058.

Osterwalder, A., \& Pigneur, Y. (2010). Business Model Generation. Amsterdam: Self Published.

Palomares-Aguirre, I., Barnett, M., Layrisse, F., \& Husted, B. W. (2018). Built to scale? How sustainable business models can better serve the base of the pyramid. Journal of Cleaner Production, 172, 4506-4513.

Pauli, G. A. (2010). The blue economy: 10 years, 100 innovations, 100 million jobs. Taos, NM, USA: Paradigm.

Pearce, D. W., \& Turner, R. K. (1990). Economics of natural resources and the environment. Balt.: John Hopkis Univerity Press.
Planing, P. (2015). Business model innovation in a circular economy reasons for non-acceptance of circular business models. Open Journal of Business Model Innovation.

Planing, P. (2018). Towards a circular economy - how business model innovation will help to make the shift. International Journal of Business and Globalization, 20, 71.

Ranta, V., Stenroos, L. A., \& Makinen, S. J. (2018). Creating value in the circular economy: A structured multiple-case analysis of business models. Journal of Cleaner Production, 201, 988-1000.

Rashid, A., et al. (2013). Resource conservative manufacturing. Journal of Cleaner Production, 57, 166-177.

Richardson, J. (2008). The business model: An integrative framework for strategy execution. Strategic Change, 17, 133-144.

Riisgaard, H., Mosgaard, M., \& Zacho, K. O. (2016). Local circles in a circular economy: The case of smartphone repair in Denmark. European Journal of Sustainable Development, 5, 109-123.

Ritala, P., Huotari, P., Bocken, N., Albareda, L., \& Puumalainen, K. (2018). Sustainable business model adoption among S\&P 500 firms: A longitudinal content analysis study. Journal of Cleaner Production, 170, 216226.

Rizos, V., Behrens, A., van der Gaast, W., Hofman, E., Ioannou, A., Kafyeke, T., Flamos, A., Rinaldi, R., Papadelis, S., Hirschnitz-Garbers, M., \& Topi, C. (2016). Implementation of circular economy business models by small and mediumSized enterprises (SMEs): Barriers and enablers. Sustainability, 8(11), 1212-1230.

Ruggieri, A., Braccini, A., Poponi, S., \& Mosconi, E. (2016). A meta-model of interorganisational cooperation for the transition to a circular economy. Sustainability, 8(11), 1153-1170. 
Sarasini, S., \& Jacob, M. (2014). Past, present, or future? managers' temporal orientations and corporate climate action in the swedish electricity sector. Organization \& Environment, 27, 242-262.

Sarasini, S., \& Linder, M. (2018). Integrating a business model perspective into transition theory: The example of new mobility services. Environmental Innovation and Societal Transitions, 27, 16-31.

Schaltegger, S., Hansen, E. G., \& LüdekeFreund, F. (2016). Business models for sustainability: Origins, present research, and future avenues. Organization \& Environment, 29, 3-10.

Scheel, C. (2016). Beyond sustainability. Transforming industrial zero-valued residues into increasing economic returns. Journal of Cleaner Production, 131, 376386.

Scheepens, A. E., Vogtlander, J. G., \& Brezet, J. C. (2016). Two Life Cycle Assessment (LCA) based methods to analyse and design complex (regional) circular economy systems. Case: Making water tourism more sustainable. Journal of Cleaner Production, 114, 257-268.

Schenkel, M., Caniëls, M. C. J., Krikke, H., \& van der Laan, E. (2015). Understanding value creation in closed loop supply chains Past findings and future directions. Journal of Manufacturing Systems, 37, 729-745.

Schulte, U. G. (2013). New business models for a radical change in resource efficiency. Environmental Innovation and Societal Transitions, 9, 43-47.

Seghetta, M., Hou, X., Bastianoni, S., Bjerre, A. B., \& Thomsen, M. (2016). Life cycle assessment of macroalgal biorefinery for the production of ethanol, proteins and fertilizers? A step towards a regenerative bioeconomy. Journal of Cleaner Production, 137, 1158-1169.

Seuring, S., \& Gold, S. (2012). Conducting content- analysis based literature reviews in supply chain management. Supply Chain Management: International Journal, 17(5), 544-555.

Singh, J., \& Ordoñez, I. (2016). Resource recovery from post-consumer waste: Important lessons for the upcoming circular economy. Journal of Cleaner Production, 134, 342-353.

Sousa-Zomer, T. T., Magalhães, L., Zancul, E., \& Cauchick-Miguel, P. A. (2018). Exploring the challenges for circular business implementation in manufacturing companies: An empirical investigation of a pay-per-use service provider. Resources, Conservation \& Recycling, 135, 3-13.

Stahel, W. (1994). The utilization-focused service economy: Resource efficiency and product-life extension. Greening of Industrial Ecosystem, 178-190.

Stewart, R., Niero, M., Murdock, K., \& Olsen, S. I. (2018). Exploring the implementation of a circular economy strategy: The case of a closed-loop supply of aluminum beverage cans. 25th CIRP Life Cycle Engineering (LCE) Conference, 30 April - 2 May 2018, Copenhagen, Denmark.

Stubbs, W., \& Cocklin, C. (2008). Conceptualizing a sustainability business model. Organization \& Environment, 21, 103-127.

Teece, D. J. (2010). Business models, business strategy and innovation. Long Range Planning, 43, 172-94.

The Ellen MacArthur Foundation. (2015). Towards a Circular Economy: Business Rationale.

Tukker, A. (2004). Eight types of product-service system: Eight ways to sustainability? experiences from SusProNet. Business Strategy \& Environment, 13, 246-260.

Tukker, A. (2015). Product services for a resource-efficient and circular economy - a review. Journal of Cleaner Production, 97, 76-91. 
Tukker, A., \& Tischner, U. (2006). Productservices as a research field: Past, present and future. Reflections from a decade of research. Journal of Cleaner Production, 14, 1552-1556.

Tunn, V. S. C., Bocken, N. M. P., van den Hende, E. A., \& Schoormans, J. P. L. (2019). Business models for sustainable consumption in the circular economy: An expert study. Journal of Cleaner Production, 212, 324-333.

Tura, N., Hanski, J., Ahola, T., Ståhle, M., Piiparinen, S., \& Valkokari, P. (2019). Unlocking circular business: A framework of barriers and drivers. Journal of Cleaner Production, 212, 90-98.

Ünal, E., Urbinati, A., \& Chiaroni, D. (2018). Managerial practices for designing circular economy business models: The case of an Italian SME in the office supply industry. Journal of Manufacturing Technology Management.

Upward, A., \& Jones, P. (2016). An ontology for strongly sustainable business models. Organization \& Environment, 29, 97-123.

Urbinati, A., Chiaroni, D., \& Chiesa, V. (2017). Towards a new taxonomy of circular economy business models. Journal of Cleaner Production, 168, 487-498.

van Buren, N., Demmers, M., van der Heijden, R., \& Witlox, F. (2016). Towards a circular economy: The role of Dutch logistics industries and governments. Sustainability, 8(7), 1-17.

van Renswoude, K., Wolde, A. ten, \& Joustra, D. J. (2015). Circular business models Part 1: An introduction to IMSA's circular business model scan. IMSA Amsterdam. http://hh.surfsharekit.nl:8080/get/ smpid:53447/DS1.

Veleva, V., \& Bodkin, G. (2018). Corporateentrepreneur collaborations to advance a circular economy. Journal of Cleaner Production, 188, 20-37.
Vogtlander, J. G., Scheepens, A. E., Bocken, N. M., \& Peck, D. (2017). Combined analyses of costs, market value and eco-costs in circular business models: Eco-efficient value creation in remanufacturing. Journal of Remanufacturing, 7(1), 1-17.

Whalen, K. (2017). Classifying circular business models: A practice-based review. In Product Lifetimes and the Environment 2017 - Conference Proceedings. Delft, The Netherlands, 8e10 November 2017.

Winans, K., Kendall, A., \& Deng, H. (2017). The history and current applications of the circular economy concept. Renewable and Sustainable Energy Review, 68, 825-833.

Wirtz, B. W., Pistoia, A., Ullrich, S., \& Gottel, V. (2016). Business models: Origin, development and future research perspectives. Long Range Planning, 49, 3654.

Witjes, S., \& Lozano, R. (2016). Towards a more Circular Economy: Proposing a framework linking sustainable public procurement and sustainable business models. Resources, Conservation and Recycling, 112, 37-44.

Wolde, A. (2016). Circular business models. In The Sustainable Innovation 2016 Conference 'Circular Economy'Innovation \& Design, Epsom, UK, 8 November 2016.

Yaduvanshi, N. R., Myana, R., \& Krishnamurthy, S. (2016). Circular economy for sustainable development in India. Indian Journal of Science \& Technology, 9, 1-9.

Yang, S., \& Feng, N. A. (2008). Case study of industrial symbiosis: Nanning sugar Co., Ltd. in China. Resources, Conservation and Recycling, 52(5), 813-820.

Yip, A. W. H., \& Bocken, N. M. P. (2018). Sustainable business model archetypes for the banking industry. Journal of Cleaner Production, 174, 150-169.

Yuan, Z., Bi, J., \& Moriguichi, Y. (2006). The circular economy: A new development strategy in China. Journal of Industrial Ecology, 10, 4-8. 
Zott, C., \& Amit, R. (2010). Business model Zott, C., Amit, R., \& Massa, L. (2011). The design: An activity system perspective. business model: Recent developments and Long Range Planning, 43, 216-226. future research. Journal of Management, 37(4), 1019-1042.

Annex. Tools supporting the CBM

\begin{tabular}{|c|c|}
\hline Tool & Authors \\
\hline $\begin{array}{l}\text { Tools for value mapping e.g. Value } \\
\text { Mapping Tool, Sustainable Analysis } \\
\text { Tool, Circularity Canvas Methodology, } \\
\text { Circular Board }\end{array}$ & $\begin{array}{l}\text { Bocken et al., 2013; Yang et al., 2014; Sustainn, 2017; Circulab, } \\
2018\end{array}$ \\
\hline Visualization tools & $\begin{array}{l}\text { Antikainen and Valkokari, 2016; Bocken et al., 2018; Breuer and } \\
\text { Lüdeke-Freund, 2014; Chiu et al., 2015; Dewulf, 2010; EMAF, } \\
\text { 2016; França et al., 2017; Jones and Upward, 2014; Joyce } \\
\text { and Paquin, 2016; Kraaijenhagen et al., 2016; Lewandowski, } \\
\text { 2016; Mentink, 2014; Nubßholz, 2018; Rohrbeck et al., 2013; } \\
\text { Sempels, 2013; Sustainn, 2017; Tiemann and Fichter, 2016; } \\
\text { Wiithaa, } 2018\end{array}$ \\
\hline Circular format & Materials, 2016 \\
\hline Life cycle format & Manninen et al., 2018; Nubholz, 2018; Yang et al., 2017 \\
\hline Arrow or process diagrams & $\begin{array}{l}\text { França et al., 2017; Kurucz et al., 2017; Sustainn, 2017; Yang } \\
\text { et al., 2014; Yang et al., } 2017\end{array}$ \\
\hline Matrices, flowcharts or loops & $\begin{array}{l}\text { Haanstra et al., 2017; Achterberg et al., 2016; Bakker et al., } \\
\text { 2014; Brehmer et al., 2018; Mentink, } 2014\end{array}$ \\
\hline
\end{tabular}

